\title{
Construction of Reflexivity in Social Workers Working with Vulnerable Children in the Czech Republic
}

\author{
Kateřina Glumbíková \\ Department of Social Work, Faculty of Social Studies, University of Ostrava, the \\ Czech Republic
}

\section{Abstract}

Social work in the Czech Republic is confronted with the impact of global neoliberalism, which is manifested by privatisation of social services, individualisation of social risks and economisation. Reflexivity of social workers working with vulnerable children and their families has the potential to lead to a higher quality of social work, strengthening of social workers' identity, and empowering social workers to promote changes in everyday practice. Meeting this potential requires an understanding of constructing reflexivity by social workers, which is the objective of this paper. We used a qualitative research strategy, particularly group and individual interviews with social workers and their analysis using current approaches to grounded theory. Concerning data analysis, we found out that constructing reflexivity (nature and subject of reflexion) derives from the perceived roles of social workers (social worker as an ununderstood artist, social worker a as mediator between social and individual, social workers as an agent of a (society) change, social workers as an agent of normalisation and reflexive professional). The acquired data, within the situational analysis, was inserted into a position map on the scale of holistic and technical reflection. The conclusion discusses the implication for practice and education in social work.

Keywords: Reflexion construction, role of social work, neoliberalism

\section{Introduction}

Social work in the Czech Republic is confronted with the impact of global neoliberalism; which is a political ideology with an economising paradigm applying the laws of the free market. The practice of social work goes though the implementation of market-oriented values, procedures, and management of social services. Neoliberalism in social work is manifested, in general, by privatising social services, individualising social risks (although most risks occur structurally, their solution is expected on an individual level), and economising and rationalising (social 
work subjects to market demands and effective requirements). ${ }^{1}$ As a result of global neoliberalism, legitimacy of social services is questioned and social workers are perceived as those who artificially create problems and help those who do not deserve their help (Chytil 2007; Valová \& Janebová 2015).

Contemporary social work in the Czech Republic thus works in the intentions of bureaucratic responses to uncertainty, complexity, risk, and anxiety, which are inherent in social work practice (Glumbíková, Vávrová \& Nedělníková 2018; similarly see Ferguson, 2005); resulting in the loss of sense of perspective (Knott \& Scragg, 2016).

Czech social work thus witnesses a reduction of beyond-rational and emotional behaviour aspects. A client is thus redefined from an "individual with difficulties" to a "service user" (see Ruch, 2005).

Authors Glumbíková, Vávrová \& Nedělníková (2018) add that social work with vulnerable children accentuates the above-mentioned with: a) social workers work with the difficult life situation of, in many cases, traumatised children who may feel distrust toward adults; b) the existence of a series of inconsistent methodological guidelines from various institutions (f. e. the ambiguous definition of concepts, such as "a vulnerable child" or "remediation of the family") and the absence of methodological guidelines on topics such as the situation of unwanted children; c) the fact that child protection service workers need to retain the trust of the client on one hand and, on the other hand, collect evidence for the potential need to "remove a child from a family".

According to many Czech authors, a lot of social workers have adapted to the abovementioned neoliberal trends in social work or they perceive them as unchangeable (Musil, 2008; Janebová, Hudečková, Zapadlová \&Musilová 2013; Valová \& Janebová 2015). Social workers thus perceive themselves as mere executors of the set social work, which come to them from the "outside" or "above" from those who do not have a direct relation to everyday practice of social work with a client (Gojová \& Glumbíková, 2015; Glumbíková, Vávrová \& Nedělníková 2018).

Within the context of the above-mentioned providing social work with vulnerable children and their families in the contemporary society, the ability of reflexivity seems to be the key skill in coping with the requirements of the current social work, which enables to deal with messy or complex problems (Mathias, 2015; Fook, 2016), to cope with uncertainties, doubts, and anxieties (Gardner, 2006; Holland, 2011; Fook, 2016), or to reveal challenging implicit discourses, knowledge system, assumptions, and values (Sanaya \& Gardner, 2012; Fook, 2016). Reflexivity in social workers has the

${ }^{1}$ Similar impacts on social work outside the Czech Republic are described, e.g., by Ruch (2005), Ferguson (2005), Fook (2016), or Knott \& Scrag (2016). 
potential to improve social work, strengthen the identity of social workers, and empower social workers to promote changes in everyday practice in this profession. In order to strengthen the social workers' ability of reflexivity, it is necessary to understand constructing 1 reflexivity by social workers working with vulnerable children and their families in the Czech Republic, which is also the objective of this paper.

1 In our text, we proceed from the thesis of social constructionism, which understands social reality as a social construct created by interaction, communication, and language. The reality is experiential, passed on from generation to generation through traditions and socialisation (Gergen, 1999). 


\section{Theoretical grounds: Reflexivity and its concepts}

Reflexivity ${ }^{1}$ can be understood as a) ability to assess the situation of a vulnerable child in the context of destabilisation or problematisation of what we consider knowledge and everyday defence of knowledge (see for example D'Cruz, Jones, 2007; Sanaya \& Gardner, 2012); b) process of looking from outside on social and cultural artefacts and forms of thinking which saturate the practice of helping professions, and questioning and challenging processes which give a meaning to the world (see for example Ferguson, 2003); c) theoretical approach which enables social workers to deal with dilemmas and identify values and the "important" in their practice (see for example Fook, Gardner, 2007). Individual authors (Schön, 1983; Gould \& Baldwin, 2004; Ruch, 2005; Taylor, 2010; Edwards, 2016) distinguish numerous perspectives/understanding a reflection.

Schön (1983) formulates two concepts of reflection: reflection-on-action and reflection-in-action. Reflection-on-action is a one-time activity that follows a meeting with a client or after some other practical activity. In the reflection-on-action, a worker studies why he/she acted, how he/she acted, what happened in the process, and considers the future strategy of acting.

Reflection-in-action is a concept that expresses the effort to continuously monitor, during the whole meeting, experiences, feelings, and concepts and theories which affect the currently ongoing meeting. It concerns a creative process which enables the social worker to get a situational view to be able to act with respect to the developing situation.

Knott and Scragg (2016) add that reflection in action requires the social worker to be experienced as it can be concerned more "intuitive and artistic" unlike "technical competence", which prevails at the side of a beginning social worker (Knott \& Scragg, 2016). Gould \& Baldwin (2004) extend the Schön's concept with a third component reflection before action, which consists of acquiring information before the client's visit and enables the worker to prepare for the client's visit and use his/her sources more effectively. Edwards (2016) extends the concept with a fourth component reflection beyond action, which "can produce the type of learning that may be vital if students are to move beyond the limited confines of mechanistic reflection in the current

\footnotetext{
${ }^{1}$ Differences between the terms reflexivity and reflectivity can be seen in the following categories a) grounding (term reflexivity stems from socially-scientific research, primarily qualitative); b) relating to the present (reflexivity is related to reflection in action, reflectivity is related with reflection on action; reflexivity is then a continuous process and reflectivity has primarily a one-time character); c) application of a finding (reflectivity creates a theory from one incident, which is then generalised and applied to other incidents or situations; reflexivity does not have this objective, it focuses on a critical attitude to creating knowledge in a given particular situation) (D'Cruz et al., 2006). In this paper, we will approach reflexivity and reflectivity according to Fook and Gardner (2007) and Fook (2016) as interchangeable.
} 
form of reflection-on-action. With the inclusion of a story of others and their sharing, the development of professional practice can be enhanced through interconnection of the past, present, and future".

Ruch (2005) talks about technical and holistically oriented reflection on social work. Technical oriented reflection on social work orientates on improving the practice by evidence what happened and how it happened. Holistically oriented reflection on social work focuses on improving the practice by searching the answer to the question of why it happened (trying to understand the meaning of action). Meanwhile, it perceives the uniqueness and complexity of each client and his/her situation, including irrational aspects. Holistic reflection is thus of an interpretative nature, is relational, dynamic, and situational; it also contains individual and structural aspects of each client's situation and stems from the respect to the practice wisdom. Taylor (2010) identifies, in accordance with Ruch (2005), technical reflection as empirically based focused on systematic and objective approaches (e.g. evidence-based practice). The author then distinguishes practical reflection, which focuses on our interactions and our expectations of interactions and on emancipatory reflection, which is concerned with power in interactions and trying to liberate people from constraints (e.g. an expert model situating knowledge and solutions in the hands of the practitioner).

\section{Methodology}

The paper presents data from research in 2018 realised within a project of Students' Grant Competition (SGC) called Critical Reflexivity of Social Workers Working with Vulnerable Children and Their Families. The main research question was set as follows: How do social workers working with vulnerable children and their families perceive critical reflexivity and how do they perceive that critical reflexivity becomes evident in social work with vulnerable children and their families? The research was implemented using a qualitative research strategy, the communication partners (informants) were selected using an intentional selection through an institution (organisations providing socially activating services for families with children ${ }^{1}$ in the

\footnotetext{
${ }^{1}$ It concerned workers of socially activating services for families with children, specified by $\$ 69$ Act 108/2006 on Social services as follows: "Socially activating services are ambulant or terrain services provided to retired persons or disabled persons endangered by social exclusion. The service according to...includes the following basic activities: a) mediating contact with social environment: It primarily concerns support of family bonds with broader social environment - with relatives, social and community (local) events, relation to peer and self-helping activities, support of participation in cultural and other events (search, accompaniment, etc.); b) social therapeutic activities: It concerns activities with children and adults focused on the development of personality, understanding oneself and situation in which the clients are, sharing and emotional support, activities focused on the support of sibling relationships and relationships between parents and children, support to understand and make clear life situations, ways of solutions and risks; c) help with assistance with asserting rights, justified interests and looking after personal matters." Socially activating services cooperate with other services and the Body of social and
} 
Czech Republic). The criteria to include an informant into the research were set as follows: a) being active in terrain social work with vulnerable children and their families; b) length of practice in terrain social work with vulnerable children and their families of at least 12 moths; c) voluntariness of taking part in the research. The research involved 12 communication partners altogether (11 women and 1 man) from three different towns in the Czech Republic. The average age of the communication partners was 30 years (the age ranged between 22 and 53 years). The average length of practice of the communication partners was 3.5 years (and ranged between 1 and 1 years). 3 communication partners had higher professional education, 9 communication partners had university education.

The data was collected using semi-structured interviews and subsequent three focus groups $(\mathrm{N}=4, \mathrm{~N}=5, \mathrm{~N}=3)$, which were systematically focused on: perception of reflexivity in the practice of social work with vulnerable children, implemented interventions in the practice of social work and relating to them, own relating of the social worker to the practice of social work, perceived context of implementing social work in the Czech Republic, and anticipated future development of social work with vulnerable children in the Czech Republic. The data was word-to-word transcribed and anonymised. The data was processed using current approaches to the grounded theory of K. Charmaz (2003) and A. Clarke et al. (2018).

The data analysis included initial coding; focused coding (which is based on searching similarities and selecting the "most useful" codes and their re-testing from the point of view of their relationship to other open codes), and intentional coding (selective phase where the most significant codes were used to synthesise, organise, and integrate a large volume of data). Next phase of coding was axial coding, which leads to the creation of categories (re-structuring data which was decomposed during open coding and thus it gives it relations) (Charmaz, 2003). Then we used the procedures of a situational analysis A: Clarke, particularly position maps, which graphically depict partakers' positions or phenomena in relations to the cross-section of (identified) factors affecting these positions (Clarke et al., 2018).

Regarding the procedures carried out within the research, they were all in accordance with the Ethical Principles of Psychologists and Code of Conduct, which were approved by the American Psychological Association (APA, 2010). Every communication partner was familiarised with research objectives; every communication partner provided the informed consent; participation in the research was voluntary and the researchers committed themselves to keep confidentiality.

Regarding the research limits, it is important to reflect that the data was collected using interviews with the communication partners the premise of which was the

legal protection of children, which is the state body with regional and city branches designed to protect the rights and interests of a child. 
ability of reflexivity of communication partners. The data in its nature is rather a perception/opinion of social workers on the reflexivity and their practice rather than a description of a real state of reflexivity in the practice of social work in the Czech Republic. Regarding the data limits, it is also necessary to reflect possible social desirability in the communication partners' expressions. Regarding the support of data validity (with respect to own reflexivity of the social workers), the data was analysed using the mechanism of mechanism inter-coder agreement.

\section{Data analysis}

The data analysis, whose aim was to understand the construction of reflexivity in social work, revealed that social workers working with vulnerable children and their families ${ }^{1}$ construct reflexivity reflexivity (nature and subject of reflexion) in social work differently in several percieved roles of social worker in social work. It concerned the role of: social worker as an ununderstood artist, social workers as a mediator between social and individual, social workers as an agent of a change (in society), social workers as an agent of normalisation and a reflexive professional. However, the individual role can be perceived as theoretical constructs which do not exist so clearly, but which intermingle and intersect in the personality of (one) social worker.

\section{Social worker as an ununderstood artist}

In the role of a social worker as an ununderstood artist (creative role), social work is perceived as the possibility of self-realisation, sense, and mission "For me, it's a kind of self-realisation." (KP12) "I see it as something like my life mission..." (KP4)

Social work in the role was perceived as a lonely profession where the working tool is the social worker. "It's a very individual work, the personality of the worker in that family is very important there ... one is alone for that situation." (KP1) Social work, however, was perceived as an intuitive profession. "Often very intuitively that one cannot say how the model is called in a textbook, but it is used like that." (KP6) The communication partners in this role agreed on the fact that social work is a continuous process of learning: "As I do not have such long practice, I take it as I'm learning all the time." (KP2)

The role of an ununderstood artists relates to the feeling of ununderstanding and undervaluing, both by society and clients. "The work itself, with this group of people, was ununderstood directly... that I'm a terrain social worker, their eyebrow rises. And

\footnotetext{
${ }^{1}$ Social workers do not explicitly state in their narrations the uniqueness of the construction of reflexivity in relation to the target group they work with; however, it is important to perceive that their construction of reflexivity stems from their everyday practice of social work with vulnerable children and their families.

2 Abbreviation KP means communication partner, the number means identification of individual communication partners.
} 
when you add that you focus on families with children, for example Gypsy families, that you help them with benefits and accommodation, ununderstanding again." (KP9)

The definition of this role of a social worker reveals that social workers' reflexions primarily focus on the personality of a social worker. Social work was perceived in the intentions of priceless and often intransferable experience, which led to the change of the personality of its executor. "I've always been such a prosocial character, but it is a profession which affects everyone; one is more humble, appreciate what he/she has when seeing people around with their existential problems. And material possessions, greed, and consumerism which predominates in our society, I think it does not touch me so much. I don't need to race for such conveniences... it's rather humbleness." (KP1)

\section{Social workers as a mediator between social and individual}

Within this role, the communication partners perceived the role of a social worker as a certain balance of the non-existence of collective responsibility in relation to unfavourable social situations and the pressure on individual responsibility for failures; their reflexion was then primarily directed to the setting of contemporary society. "In many clients, it can't be said who's guilty... mostly it's the society and the setting that we have here; for example there are no town flats and multiple families then end up in quarters as they can't find such big flats..." (KP12)

In the context of this role, the communication partners reflected that social work is perceived as necessary even in "problems that get worse". "Problems of those clients are worse, I think." (KP7) "As the population is getting older, social work is really more and more needed, no one else can take care of those people." (KP6)

\section{Social worker as an agent of a change (in society)}

The role of a social worker as an agent of a change in society is defined by reflexion of the absence of a system approach to solving problems. In this context, one of the communication partners reflected the current situation in the area of social housing "At the moment, I think that most of our practice is influenced by the pressure to close down the quarters and change it to rental housing. Many families cannot afford it. So closing down the quarters pushes them to the hands of resellers of these flats as they cannot go anywhere else." (KP8) Another communication partner pointed out the setting of the system of benefits "I see it that the benefit system is badly set. Those who don't work often receive more... it's not motivating. "(KP5)

Other reflexions were focused on "problems with legislation" which is not set in social work "bottom-up". "The biggest problem is in laws. Seems like... social workers do their work well, but it is the state which throws a monkey wrench into the works." (KP5) „And the best should be that those up should try it, touch this work, they should 
change..." (KP7) Concerning this setting, the communication partners pointed out increasing bureaucratisation of social work, which sucks out the time for direct work with a client. "Half of the work time is paperwork about what I do... I'd rather work with clients, but can't - have to write: I did this and that. Reports. I have to prove to somebody what I do so that someone knows as we are paid. This really annoys me." (KP6) Another communication partner was critical to the system of setting interventions within a project, where it is necessary to meet obligatory quota. She pointed out a paradox in social work as the objective of social work is that a client does not need the social worker in the future, but the social worker needs them to fulfil this profession. "But we need the clients... because we need to meet the interventions. I reckon that sometimes there's a kind of contradiction as I need to gain these interventions and I'm happy that the client does not do it by himself/herself because I need to have these interventions and if the client did many things by himself/herself, I can't gain the interventions." (KP10)

Social workers stated that due to the above-mentioned, they lose the sense of social work. "I think that there is a lack of the view from the practice point of view. It's done by people behind a table. We have to follow certain norms and regulations and I have to spend certain hours in the terrain and then write individual plans which the client changes our times during one meeting. I understand that we have to do it, so I do it, but I see no sense in it." (KP11)

Social work in the role of a social worker a $s$ an agent of a change in society is perceived as a filed having a certain potential. "I still think that social work does not achieve what it could achieve." (KP1) "Social work is quite developing thanks to those projects and so on. Yes, it's going up, but still does not meet its potential." (KP2)

\section{Social worker as an agent of normalisation}

The role of a social worker as an agent of normalisation is a position when the objective of social work is to "reform" the client according to valid norms in the society. Social workers in their narrations perceived this role as oppressive and they rather connected it with expectations of the society towards social workers and worries of clients from the scope of work of a social worker. The communication partners related this role with the check of the "asocial". "Some (clients) take us as the tool of such a check and that we go there to take their children away." (KP8)

The check of the "asocial" was related by the communication partners with a perceived discourse of merit, which appears in the contemporary society. "The public doesn't see it that sometimes they (note: clients) got into it by their own mistake, sometimes it was just a coincidence of many circumstances." (KP4) "And one friend tells me that she does not understand how I can help such people as they got into the situation by themselves."(KP11) 
In this role, social workers mostly relate reflexivity with the process of executing social work, particularly it is perceived as a tool of setting boundaries of work with a client, freeing from work with a lie from the client's side. "I free myself for example like that... I just simply take it that it is work and I won't go to have a coffee with the client, I just do my work and I give the man what I can give." (KP3). In this context, the communication partners considered reflexivity as a tool to set the level of trust in a client. "Those are really beginner's mistakes with the trust..., one wants to see the people positively, one wants to believe." (KP10) Another communication partner perceived critical reflexivity as a tool of work with a failure to meet what was agreed on with the client. "They want something, we work hard on it and I see that they haven't done a single thing they were supposed to do... go somewhere with son's application for school... I'm always so surprised that those people want something, but then don't do anything for that." (KP10)

\section{Reflexive professional}

The role of a reflexive professional can be related with holistic reflexivity, which is refers to improving the practice of social work by its reflexion. This reflexion is focused on the uniqueness of each client and each situation in its individual and structural aspects. Reflexivity in this context is understood as a "tool of healthy doubts". "But I think that if a social were one hundred per cent sure about what he/she is doing, it would not be good either..." (KP8) Reflexivity was also perceived as a tool of work with own mistake "I it is a mistake... meaning that I didn't behave professionally, but the client didn't consider it a... misstep... I solve this situation differently... I get back to this topic and we discuss it a bit differently." (KP1)

Reflexivity in the role of a reflexive professional is understood as a tool of understanding client's behaviour. "I might have been disconcerted by client's reaction as I didn't see any reason for that. But looking back I thought... yes... that there might have been some reason..." (KP2) This understanding will subsequently result in the avoidance of taking a judging attitude towards the client. „I think that clients really appraise I consider it quite crucial for me that they see some understanding from the social worker's part and that there is no a priori judgement of the behaviour." (KP4) Reflexivity was also perceived as a tool to accept the client's norm by the social worker. "Just get closer to the level of the family, don't criticise. I take it as it is. I perceive it that the client needed it. If they knew to do it better, they would do it better." (KP6)

Reflexivity was also perceived as a tool enabling to work with a client in (more) empowering ways. "We come to a mutual conclusion how to solve it... I don't help them indeed... rather motivate.” (KP6) „I see myself not as a directive tool. If a client tells me that he/she doesn't want to take this alternative to solve the situation, I can't force them. I can only explain the situation in the case that they wouldn't like to solve the situation, where it might end up." (KP8) The communication partners perceived reflexivity as a tool supporting an approach focused on the support of competencies and 
strengths. "An approach as something like praising... not praising like a small child, but rather highlight what they did." (KP9)

In the narration, the communication partners perceived the role of a reflexive professional as a certain ideal to head towards. "I would like to be that empowering social worker who is aware of and works with the whole system, but there is a long journey and a lot of support." (KP1)

\section{Positional map of social workers' role related to the subject and nature of reflexion}

The above-mentioned roles of social workers (partakers') were related with the theoretical concept by Ruch (2005) on technical-oriented and holistically-oriented reflection (nature of reflexion) (identified factors affecting roles of social workers).

Thus, a positional map was created. It depicts the above-mentioned roles of social workers according to the subject of reflexion (society, process, client's personality, worker's personality) and according to the use of technical-oriented reflection a holistically-oriented reflection (nature of reflexion).

Scheme 1: Positional map of social workers in relation to the subject and nature of reflexion

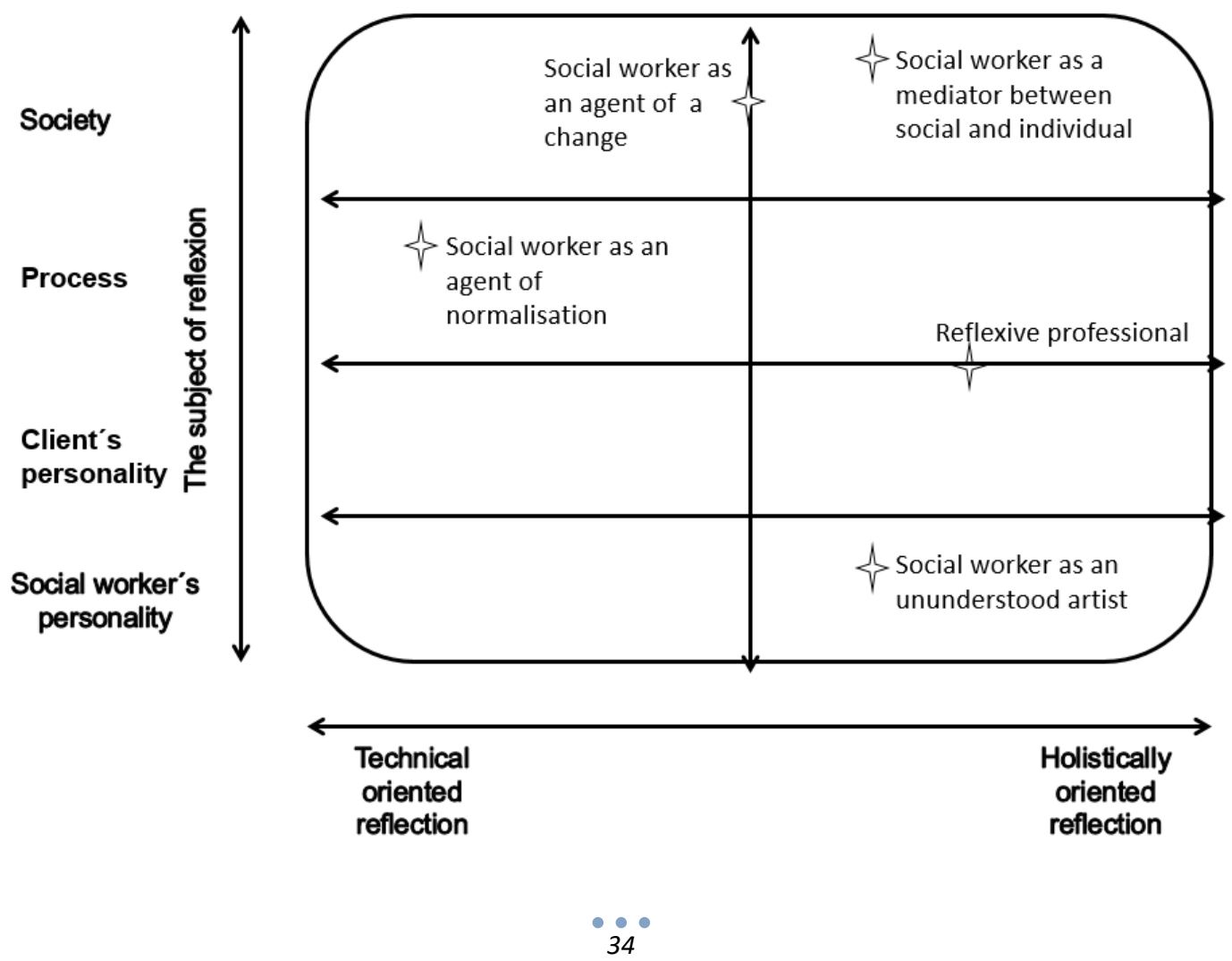


Source: Own construction.

The above-presented positional map reveals that two roles of social workers (Social worker as an agent of a change and Social worker as an agent of normalisation) can be perceived in the concept of Technical-oriented reflection, when their reflexion stems from the practice evidence and systemic and objective approaches. The subject of a Social worker as an

Agent of a change is society while the subject of a Social worker as an agent of normalisation is the process of social work. Three roles of social workers (Social worker as a mediator between social and individual, Reflexive professional and Social worker as an ununderstood artist) can be perceived within the concept of Holisticallyoriented reflection. The social worker in these roles focuses on improving the practice using reflexion of searching the answer to the question why happened what happened (they try to understand the meaning of happening) while perceiving the uniqueness and complexity of each client and each situation, including irrational aspects.

\section{Discussion and implications for social work}

The data analysis revealed that constructing reflexivity depends on the roles perceived by social workers. Each created role, however, must be perceived as a certain (ideal) theoretical construct as roles of social workers are of an intersectional nature and thus intersect and mingle depending on a specific context of social work. The above-presented positional map shows that the identified roles of social workers fluctuate in a certain continuum of "doing social work" and "being a social worker" (see Ruch, Harrison, 2007). An important finding is that the role of a reflexive professional was marked in the narrations as a certain "ideal" to head towards rather than a matter of everyday practice. When defining the role of a reflexive professional, it is obvious that reflexion has the potential to create more inclusive and less judging practice (similarly see Jones, 2010); to work in more empowering ways (similarly see Fook, 2016); and to create practice less focused on finding a solution and more on building clients' abilities (Fook \& Gardner, 2007; Fook, 2016).

Reflexion in the created roles related to various subjects in social practice, such as society, process, personality of a client, or personality of a worker. The research results thus show that reflexion has a wide range of focus which has a potential to empower social workers in relation to a possible change in the setting of social work practice. It seems that it is thanks to reflexion that social workers can become aware that they are not only mere executors of the "above" given setting, but their role in this process is more active. They are implementers who develop own coping strategies helping them, within limited resources, manifest own decision making. It is those processes that enable social workers to shape public policy right when interacting with clients (Lipsky, 2010). 
In the context of the above-mentioned, it can be stated that strengthening of the ability of holistic reflexivity of social workers (not only in the Czech Republic) should be included in a standard curriculum of social workers (similarly see, for example, Tate \& Sills, 2004; or Guransky et al., 2010) and to further education of social workers working with vulnerable children and their families. The first step to include this in the Czech Republic was understanding how Czech social workers construct reflexivity in the practice of Czech social work. The above-stated data shows that integrating into education should have the nature of offering opportunities and platforms to reflect experience from the practice. A roofing concept of this education should be experiential learning, which is based on sharing experience. A particular form of integration into education can be supervisions, intervisions, team meetings, or, for example, using reflexive diaries (similarly see Barlow \& Hall, 2007; Grant et al., 2014;).

\section{Conclusion}

We gained understanding about constructing reflexivity by social workers working with vulnerable children and their families in the Czech Republic, which is also the objective of this paper. The data analysis revealed that constructing reflexivity depends on the roles perceived by social workers.

\section{References}

[1] Act n. 108/2006 Sb. The Social Services Act

[2] American Psychological Association. (2010). Ethical Principles of Psychologists and Code of Conduct. Retrieved from http://www.apa.org/ethics/code/

[3] Bauman, Z. (1987). Legislators and Interpreters: On Modernity, PostModernity and Intellectuals. Oxford: Polity Press.

[4] Barlow, C., \& Hall, B. L. (2007). What about feelings? A study of Emotion and Tension in Social Work Field Education. Social Work Education, 26(4), 399413.

[5] Clarke, A., Friese, C., \& Washburn, R. (2018). Situational Analysis in Practice: Grounded Theory After the Interpretative Turn. London: SAGE.

[6] D'Cruz, H., \& Jones, M. (2004). Social Work Research: Ethical and Political Contexts. London: Sage.

[7] D'Cruz H., Gillingham, P., \& Mendez, S. (2007). Reflexivity: A Concept and Its Meanings for Practitioners Working with Children and Families. Critical social work, 8(1), 1-18.

[8] Holland, S. (2011). Assessment in Social Work Practice. London: Sage Publications.

[9] Edwards, S. (2016). Reflectin Differently: New Dimensions Reflectionbefore-action and Reflection-beyond-action. International practice Development Journal, 7(1), 1-14. 
[10] Ferguson, H. (2005). Working with Violence, the Emotions and the Psychosocial Dynamics of Child Protection:Reflections on the Victoria Climbié Case. Social work education, 24(7) 781 - 795.

[11] Ferguson, H. (2003). Welfare, Social Exclusion and Reflexivity: The Case of Child and Woman Protection. Journal of Social Policy, 32(2), 199-216.

[12] Fook, J. (2016). Researching Critical Reflection. Multidisciplinary Perspectives. NY: Routledge.

[13] Fook, J, \& Gardner, F. (2007). Practicing critical reflection: A resource handbook. Berkshire: Open university press.

[14] Forrester, D., McCambridge, J., Waissbein, C., \& Rollnick, S. (2008). How do Child and Family Social Workers Talk to Parents about Child Welfare Concerns? Child abuse Review, 17, 23-35.

[15] Gardner, F. (2006). Working with Human Service Organisations: Creating Connections for Practice. Melbourne: Oxford University Press.

[16] Gergen, K. J. (1999). An invitation to social construction. London: SAGE Publications.

[17] Glumbíková, K., Vávrová, S., \& Nedělníková, D. (2018). Optiky Posuzování v Agendě Sociálně-právní Ochrany Dětí [Optics of Assessment in the Agenda of Social-legal Protection of Children]. Sociální práce/Sociálná práca, 18(6), 78 - 88.

[18] Gojová, A., \& Glumbíková, K. (2015). Bezmocná Sociální Práce jako Zdroj Zplnomocnění [Powerless Social Work as a Source of Empowerment]. Sociální práce/Sociálná práca, 16(5), 52 - 64.

[19] Gould N., \& Baldwin, M. (2004). Social work, Critical Reflection and the Learning Organization. Aldreshot: Ashgate.

[20] Grant, L., Kinman, G., \& Alexander, K. (2014). What's all this talk about emotion? Developing emotional intelligence in social work students. Social Work Education, 33(7), 874-889.

[21] Gursansky, D., Quinn, D., \& Le Sueur, E. (2010). Authenticity in Reflection: Building Reflective Skills for Social Work. Social Work Education, 29(7) 778-791.

[22] Healy, K. (2005). Social work theories in context: Creating frameworks for practice. Basingstoke, Palgrave MacMilan.

[23] Charmaz, K. (2003). Qualitative Interviewing and Grounded Theory Analysis. In Holstein, J., \& Gubrium, J. F. (Eds.), Inside Interviewing. New Lenses, New Concerns (pp. 311-330). Thousand Oaks, London, New Delhi: SAGE Publications.

[24] Chytil, O. (2007). Důsledky Modernizace pro Sociální Práci [Consequences of Modernisation for Social Work]. Sociální práce/Sociálná práca, 4, 64 - 71.

[25] Janebová, R., Hudečková, M., Zapadlová, M., \& Musilová, J. (2013). Př́běhy Sociálních Pracovnic a Pracovníků, kteří Nemlčeli - Popis 
Prožívaných Dilemat [Tales of Social Workers who did not Stay Silent -

Description of Experienced Dilemmas]. Sociální práce/Sociálna práca, 13(4), 66-83.

[26] Jones, C. (2010). Voices from the Front Line: State Social Workers and New Labour. British Journal of Social Work, 31, 547-562.

[27] Kane, G. (2007). Step-by-step: A Model for Practice-based Learning. The Journal of Continuing Education in the Health Professions, 27(4) 220-226.

[28] Knott, CH., \& Scragg, T. (2016). Reflective Practice in Social Work. London: Sage.

[29] Lipsky, M. (2010). Street Level Bureaucracy: Dilemmas of the Individual in Public Services. NY: The Russell Sage Foundation.

[30] Mathias, J. (2015). Thinking Like a Social Worker: Examining the Meaning of Critical Thinking in Social Work. Journal of Social Work Education. 51, 457-474.

[31] Munro, E. (2011). The Munro Review of Child Protection. Final Report - A Child-centred System. London: Department of Education.

[32] Musil, L. (2008). Různorodost Pojetí, Nejasná Nabídka a Kontrola Výkonu „Sociální Práce“ Práci [Diversity of Conception, Unclear Offer and Control of Performance of Social Work]. Sociální práce/Sociálna práca, 8(2), 60-79.

[33] Ruch, G. (2005). Relationship-based Practice and Reflective Practice: Holistic Approaches to Contemporary Child Care Social Work. Child and Family Social Work, 10, $111-123$.

[34] Ruch, G., \& Harrison, K. (2007). Social Work and the Use of Self: On Becoming and Being Social Worker. In Lymbery, M., Postle K., (eds.). Social Work: A Companion to Learning. Pp. 40 - 50. London: Sage.

[35] Sanaya, R., \& Gardner, F. (2012). Critical Reflexion to Identity Gaps between Espoused Theory and Theory in Use. Social Work, 57(2), 145-154.

[36] Schön, D. (1991). The Reflective Practitioner: How Professionals Think in Action. Aldershot: Ashgate.

[37] Tate, S., \& Sills, M. (Eds.). (2004). The Development of Critical Reflection in the Health Professions. London: LTSN Centre for Health Sciences and Practice.

[38] Taylor, B. J. (2010). Reflective Practice for Health-care Professionals: A Practical Guide. Berkshire: Open University Press.

[39] Thompson, N., \& Pascal, J. (2012). Developing Critically Reflective Practice. Reflective Practice, 13(2), 311-325.

[40] Valová, H., \& Janebová, R. (2015). „Antiradikálnost“ Českých Sociálních Služeb aneb jak Organizace Sociálních Služeb Řeší Pokles Finančních Prostředků [The Anti-radicalism of Czech Social Services or how Social Services Organisations Solves the Decline in Funds]. Sociální práce/Sociálna práca, 15(1), 5 -23. 
